\title{
APPLICATION OF COOPERATIVE LEARNING MODEL INDEX CARD MATCH TYPE IN IMPROVING STUDENT LEARNING RESULTS ON COMPOSITION AND COMPOSITION FUNCTIONS OF FUNCTIONS INVERS IN MAN 1 MATARAM
}

\author{
Syahrir \\ IKIP Mataram \\ Email: syahrir@ikipmataram.ac.id
}

\begin{abstract}
Lack of student response in learning mathematics caused by passive of student in process of learning progress so that the students consider mathematics subject is difficult subject to be understood. The research is Classroom Action Research (CAR) using 2 cycles and then the purpose of this research is how the implementation of cooperative learning type of index card match in improving student learning outcomes on the subject matter of composition function and inverse function in MAN 1 Mataram. While the results of the analysis in the study showed that there is in cycle I obtained classical completeness $78.79 \%$ with the average score of student learning outcomes 69.78 and the average value of student learning responses with the category Enough, then in cycle II shows that classical thoroughness $87.89 \%$ with mean score of student learning result 78.94 and average value of student learning response with good category. So it can be concluded that the implementation of Model Cooperative Learning Type Index Card Match can improve student learning outcomes on the subject matter of composition function and inverse function.
\end{abstract}

Keywords: cooperative learning, index card match, student learning result.

\section{PENDAHULUAN}

Mutu pendidikan matematika dapat di tingkatkan melalui usaha pengembangan kurikulum, peningkatan proses belajar mengajar dan peningkatan sumber daya manusia. Kegiatan belajar mengajar dapat dilakukan secara mandiri (melalui pengalaman) maupun melalui lembaga (sekolah). Sekolah merupakan tempat kegiatan belajar dimana terjadi interaksi antara guru dan siswa. Kegiatan belajar tidak lepas dari peranan guru orang tua, serta sumber belajar yang mendukung proses belajar baik disekolah maupun dirumah.

Sedangkan, sistem pembelajaran yang ditemukan pada saat ini, khususnya pembelajaran matematika masih banyak yang didominasi oleh pembelajaran yang menggunakan metode ceramah dan tanya jawab. Hal tersebut sesuai dengan Syahrir (2010:4) yang menyatakan bahwa dalam pendidikan formal seperti sekolah sudah sejak lamaguru-gurunya menggunakan metode ceramah. Kegiatan belajar tersebut hanya didominasi oleh guru, siswa hanya mengikuti apa yang diinstruksikan oleh guru dalam kelas. Untuk itu pengembangan atau variasi dalam mengunakan model, metode, strategi, serta teknik yang berbeda dapat meningkatkan hasil belajar siswa. Syahrir \& Elma H (2017:440) menjelaskan bahwa Aspek kemampuan berpikir kreatif yang digunakan dalam penelitian ini yaitu (a) kemampuan berpikir lancar, (b) kemampuan 
berpikir luwes, (c) kemampuan memperinci, (d) kemampuan berpikir orisinal, dan (e) kemampuan menilai

$$
\text { Selanjutnya Model }
$$

pembelajaran yang dapat dijadikan alternatif dalam memecahkan masalah dalam meningkatkan hasil belajar siswa tersebut adalah dengan menggunakan model pembelajaran cooperative tipe index card match. Menurut Huda (2011), model pembelajaran cooperative mengutamakan kerjasama dalam menyelesaikan permasalahan untuk menerapkan pengetahuan dan ketrampilan dalam rangka mencapai tujuan pembelajaran. Setiap model pembelajaran juga memiliki tipe yang bermacam- macam. Salah satunya, yaitu model pembelajaran cooperative tipe index card match. Menurut Suprijono (2011:120), index card match merupakan model pembelajaran yang menyenangkan. Model index card match yang berarti mencari jodoh kartu tanya jawab yang dilakukan secara berpasangan, dapat membantu siswa untuk ikut serta dalam pembelajaran secara aktif.

Bedasarkan hasil wawancara dengan siswa kelas XI IPA3 di MAN 1 Mataram bahwa permasalahan yang mendasar yang dihadapi siswa adalah rendahnya motivasi siswa dalam menerima pelajaran. Hal tersebut ditandai dengan siswa pasif dalam proses pembelajaran dan kurang memperhatikan penjelasan guru tentang materi yang disampaikan dikelas dan siswa menganggap bahwa pelajaran matematika adalah pelajaran yang membosankan. Model pembelajaran yang biasadigunakan dalam pembelajaran dikelas oleh guru mata pelajaran matematika di MAN 1 Mataram adalah metode ceramah dan penugasan.

Berdasarkan sumber arsip data guru matematika MAN 1 Mataram nilai rata-rata ujian tengah semester genap mata pelajaran matematika kelas XI IPA3 adalah 67,51dengan ketuntasan klasikal (KK) 82,41\% dan nilai rata-rata tiap pokok mata pelajaran semester dua,yaitu fungsi komposisi dan fungsi invers adalah 66,79 dengan ketuntasan klasikal $73,91 \%$, limit fungsi 68,08 ketuntasan klasikal $86,36 \%$ dan diferensial (turunan) 67,79 ketuntasan klasikalnya $86,96 \%$. Dari data tersebut, nilai ratarata ujian tengah semester genap mata pelajaran matematika ketuntasan klasikalnya kurang dari ketuntasan klasikal nasional yakni lebih besar dari sama dengan $85 \%$, dengan ratarata paling rendah pada materi fungsi komposisi dan fungsi invers.

Penelitian ini bertujuan untuk mengetahui peningkatan hasil belajar siswa melalui penerapan model Cooperative Learning tipe Index Card Match pada materi pokok fungsi komposisi dan fungsi invers di MAN 1 Mataram.

\section{METODE PENELITIAN}

Jenis penelitian ini adalah Penelitian Tindakan Kelas (PTK) yang merupakan suatu pencermatan terhadap kegiatan yang disengaja dimunculkan dan terjadi dalam kelas. Sejalan dengan hal tersebut Arikunto $(2010 ; 131)$ menyatakan bahwa rancangan Penelitian Tindakan Kelas (PTK) dilakukan dengan siklus berulang.

Rancangan dalam penelitian tindakan kelas diawali dengan perencanaan tindakan penerapan tindakan, mengobservasi dan mengevaluasi proses dari hasil tindakan, dan melakukan refleksi, dan seterusnya sampai perbaikan atau peningkatan yang diharapkan sesuai dengan indikator keberhasilan.

Adapun instrumen yang 
digunakan dalam penelitian ini adalah: (1) instrument utama yaitu peneliti itu sendiri; dan (2) instrumen pendukung yaitu; a) soal evaluasi; b) lembar observasi aktivitas guru dan siswa, c) rencana pelaksanaan pembelajaran (RPP); d) angket respon belajar siswa.

Untuk menganalisis data yang telah diperoleh dari hasil penelitian tindakan kelas ini adalah untuk data hasil belajar siswa dan angket respons belajar sisiwa akan dianalisis dengan persentase, rata-rata ideal, standar deviasi ideal, ketuntasan klasikal dan ketuntasan individu sedangkan hasil observasi aktivitas guru dan siswa ratarata, standar deviasin baik aktivitas guru maupun aktivitas siswa.

\section{HASIL PENELITIAN DAN PEMBAHASAN}

\section{Siklus I}

Tabel 1. Data Hasil Observasi Aktivitas Guru Siklus I

\begin{tabular}{|c|c|c|c|}
\hline \multirow{2}{*}{ No } & \multirow{2}{*}{ Indikator } & \multicolumn{2}{|c|}{ Jumlah Skor } \\
\hline & & Pertemuan I & Pertemuan II \\
\hline 1 & Kesiapan siswa belajar & 3 & 4 \\
\hline 2 & Pemberian motivasi dan apersepsi & 4 & 4 \\
\hline 3 & $\begin{array}{l}\text { Membimbing siswa memulai } \\
\text { pembelajaran dengan kartu }\end{array}$ & 4 & 4 \\
\hline 4 & $\begin{array}{l}\text { Membimbing siswa dalam } \\
\text { menemukan pasangan jawaban kartu }\end{array}$ & 4 & 4 \\
\hline 5 & Penutup & 3 & 3 \\
\hline & Jumlah Skor Aktivitas Guru & 18 & 19 \\
\hline & Rata-Rata Aktivitas Guru & \multicolumn{2}{|c|}{18,5} \\
\hline & Kategori & \multicolumn{2}{|c|}{ Baik } \\
\hline
\end{tabular}

Tabel 1 diatas, diperoleh rata-rata skor aktivitas guru 18,5 dengan kategori baik. Pada siklus I masih ada indikator yang belum terlaksana. Adapun beberapa kekurangan yang dihadapi guru yaitu: a) guru tidak memberikan kesempatan siswa untuk bertanya tentang apa yang belum dipahami, b) guru tidak menyampaikan tujuan pembelajaran, c) guru tidak bersama sama dengan siswa untuk menyimpulan materi yang diajarkanya.

Adapun hasil analisis respon belajar siswa pada siklus I, yaitu sebagai berikut.

Tabel 2. Data hasil Respon Belajar Siswa siklus I

\begin{tabular}{|c|c|c|c|c|c|}
\hline \multicolumn{7}{|c|}{ Respon Belajar Siswa (\%) } \\
\hline & $\begin{array}{c}\text { Sangat } \\
\text { Baik }\end{array}$ & Baik & Cukup & Kurang Baik & $\begin{array}{c}\text { Sangat } \\
\text { Kurang Baik }\end{array}$ \\
\hline & - & $54,54 \%$ & $45,45 \%$ & - & - \\
\hline Rata-Rata & \multicolumn{5}{|c|}{58,27} \\
\hline Kategori & \multicolumn{7}{c|}{ Cukup } \\
\hline
\end{tabular}

Tabel 2 diatas menunjukkan, bahwa persentase respon belajar siswa pada siklus I dengan Kriteria Baik $54,54 \%$, dan kriteria cukup $45,45 \%$. 
Jadi rata-rata respon belajar siswa secara keseluruhan mencapai 58,27 dengan kategori cukup. Ini menunjukan respon siswa untuk mempelajari fungsi komposisi, dengan melakukan diskusi sesuai dengan model pembelajaran cooperative learning tipe index card match belum mencapai indikator keberhasilan, yaitu respon belajar siswa minimal berkategori Baik.

Data tentang evaluasi hasil belajar siswa pada siklus I yang telah dilaksanakan adalah sebagai berikut.

Tabel 3. Data Hasil Belajar Siswa siklus I

\begin{tabular}{|c|l|c|}
\hline No & \multicolumn{1}{|c|}{ Data Evaluasi Siklus I } & Jumlah \\
\hline 1 & Jumlah siswa & 35 \\
\hline 2 & Siswa yang mengikuti tes & 33 \\
\hline 3 & Siswa yang tidak mengikuti tes & 2 \\
\hline 4 & Siswa yang tuntas & 27 \\
\hline 5 & Siswa yang tidak tuntas & 6 \\
\hline 6 & Nilai Maksimum & 97 \\
\hline 7 & Nilai Minimum & 50 \\
\hline 8 & Nilai rata-rata & 69,78 \\
\hline 9 & Ketuntasan Klasikal (\%) & $78,79 \%$ \\
\hline
\end{tabular}

Tabel 3 diatas, menunjukkan bahwa nilai rata-rata 69,78 , dengan ketuntasan klasikal yang tercapai sebesar $78,79 \%$. Hal ini menunjukan bahwa penelitian pada siklus I ini belum mencapai indikator keberhasilan, yaitu ketuntasan klasikal $\geq 85 \%$.

\section{Siklus II}

Adapun analisis hasil aktivitas guru adalah sebagai berikut:

Tabel 4. Data Hasil Observasi Aktivitas Guru Siklus II

\begin{tabular}{|c|c|c|c|}
\hline \multirow{2}{*}{ No } & \multirow{2}{*}{ Indikator } & \multicolumn{2}{|c|}{ Jumlah Skor } \\
\hline & & Pertemuan I & Pertemuan II \\
\hline 1 & Kesiapan siswa belajar & 4 & 4 \\
\hline 2 & Pemberian motivasi dan apersepsi & 4 & 3 \\
\hline 3 & $\begin{array}{l}\text { Membimbing siswa memulai } \\
\text { pembelajaran dengan kartu }\end{array}$ & 4 & 4 \\
\hline 4 & $\begin{array}{l}\text { Membimbing siswa dalam } \\
\text { menemukan pasangan jawaban kartu }\end{array}$ & 4 & 4 \\
\hline 5 & Penutup & 4 & 4 \\
\hline \multicolumn{2}{|r|}{ Jumlah Skor Aktivitas Guru } & 20 & 19 \\
\hline & Rata-Rata Aktivitas Guru & \multicolumn{2}{|c|}{19,5} \\
\hline & Kategori & \multicolumn{2}{|c|}{ Sangat Baik } \\
\hline
\end{tabular}

Tabel 4 diatas terlihat bahwa ratarata skor aktivitas guru 19,5 dengan kategori sangat baik. Hal tersebut dapat dikatakan guru berhasil menerapkan cooperative learning tipe index card match dalam kegiatan pembelajaran.

Adapun hasil analisis angket respon belajar siswa yaitu sebagai berikut. 
ISSN 2089-8703 (Print) Vol. 6, No. 3 (2017)

ISSN 2442-5419 (Online)

Tabel 5. Data Hasil Observasi Aktivitas Siswa Siklus II

\begin{tabular}{|c|c|c|c|c|c|}
\hline \multicolumn{7}{|c|}{ Respon Belajar Siswa (\%) } \\
\hline & $\begin{array}{c}\text { Sangat } \\
\text { Baik }\end{array}$ & Baik & Cukup & Kurang Baik & $\begin{array}{c}\text { Sangat } \\
\text { Kurang Baik }\end{array}$ \\
\hline & $6,06 \%$ & $66,67 \%$ & $27,27 \%$ & - & - \\
\hline Rata-Rata & \multicolumn{5}{|c|}{62,79} \\
\hline Kategori & \multicolumn{7}{|c|}{ Baik } \\
\hline
\end{tabular}

Tabel 5 diatas, dapat dilihat bahwa persentase motivasi belajar siswa pada siklus II secara klasikal dengan kriteria sangat Baik 6,06\%, kriteria Baik $66,67 \%$, dan kriteria cukup 27,27\%. Jadi rata-rata respon belajar siswa secara keseluruhan mencapai 62,81 dengan kategori Baik. Hasil analisis respon belajar siswa pada siklus II terjadi peningkatan, yaitu dimana pada siklus I rata-rata respon belajar siswa 58,27 dengan kategori cukup, meningkat pada siklus II menjadi 62,79 kategori Baik. Dengan menerapkan model pembelajaran cooperative tipe index card match siswa lebih responsif untuk belajar karena dalam proses pembelajaran siswa dituntut untuk aktif dan melakukan diskusi yang menciptakan suasana yang aktif dan menyenangkan.

Data tentang hasil evaluasi belajar siswa pada siklus II adalah sebagai berikut;

Tabel 6. Data Hasil Evaluasi Pembelajaran Siklus II

\begin{tabular}{|c|l|c|}
\hline No & \multicolumn{1}{|c|}{ Data Evaluasi Siklus II } & Jumlah \\
\hline 1 & Jumlah siswa & 35 \\
\hline 2 & Siswa yang mengikuti tes & 33 \\
\hline 3 & Siswa yang tidak mengikuti tes & 2 \\
\hline 4 & Siswa yang tuntas & 29 \\
\hline 5 & Siswa yang tidak tuntas & 4 \\
\hline 6 & Nilai Maksimum & 100 \\
\hline 7 & Nilai Minimum & 50 \\
\hline 8 & Nilai rata-rata & 78,94 \\
\hline 9 & Ketuntasan Klasikal (\%) & $87,89 \%$ \\
\hline
\end{tabular}

Tabel 6 diatas menunjukkan ketuntasan belajar siswa secara klasikal adalah $87,89 \%$, hal ini menunjukkan bahwa indikator keberhasilan untuk hasil belajar siswa sudah mencapai ketuntasan klasikalnya melebihi standar ketuntasan minimal, yaitu $\geq 85 \%$.

\section{Pembahasan}

Berdasarkan hasil analisis data yang telah diuraikan diatas, maka secara deskriptif hasil penelitian tindakan kelas mengungkapkan adanya peningkatan hasil belajar siswa pada materi pokok fungsi komposisi dan fungsi invers siswa kelas XI IPA MAN 1 Mataram, setelah pelaksanaan tindakan melalui penerapan model pembelajaran Cooperative tipe Index Card Match. Hasil penelitian ini menunjukan adanya peningkatan hasil belajar siswa, aktivitas guru, aktiviats siswa maupun respon belajar siswa setelah pelaksanaan tindakan siklus I dan setelah pelaksanaan tindakan siklus II berlangsung. 
Berdasarkan hasil observasi dan evaluasi pada siklus II dapat dikatakan bahwa respon belajar siswa mengalami peningkatan. Dilihat dari respon belajar siswa yaitu mengalami peningkatan dari siklus I rata-rata sebesar 69,78 kategori cukup menjadi 78,94 pada siklus II dengan kategori Baik. Begitu juga dengan persentase ketuntasan klasikal hasil belajar siswa,dimana pada siklus I ketuntasan klasikal hanya mencapai $78,79 \%$ meningkat menjadi $87,89 \%$ pada siklus II artinya dari hasil menerapkan model pembelajaran Cooperative tipe index card match sudah memenuhi standar indikator keberhasilan.

Berdasarkan uraian pembahasan di atas, terlihat bahwa terjadi peningkatan hasil belajar siswa pada materi pokok fungsi komposisi dan fungsi invers siswa kelas XI IPA3 MAN 1 Mataram, setelah pelaksanaan tindakan melalui penerapan model pembelajaran Cooperative tipe Index Card Match. Hal ini ditandai dengan adanya peningkatan kategori tinggi terhadap hasil evaluasi belajar siswa, respon siswa dari cukup mengalami peningkatan ke kategori Baik dan skor rata-rata yang diperoleh siswa dari hasil pemberian tes tertulis. Hal ini mengindikasikan perhatian, minat, motivasi serta respon siswa materi pelajaran matematika sangat baik. Senada dengan hasil penelitian Khalik Munardy Abu Kasim, K.M.A, dkk (2017;275) Perbaikan dalam Kelompok Sehingga kerja sama antar Kelompok Lebih Hidup dan tidak hanya mengandalkan satu orang saja.

Disamping terjadinya peningkatan peningkatan hasil belajar siswa pada materi pokok fungsi komposisi dan fungsi invers siswa kelas XI IPA3 MAN 1 Mataram, setelah pelaksanaan tindakan melalui penerapan model pembelajaran Cooperative tipe Index
Card Match. juga terjadi beberapa perubahan sikap siswa selama mengikuti proses pembelajaran berlangsung yaitu : Kehadiran siswa mengikuti kegiatan belajar mengajar semakin meningkat. Hal ini ditandai dengan semakin berkurangnya siswa yang tidak hadir pada saat proses belajar mengajar berlangsung pada pelajaran matematika, Peran serta siswa untuk menjawab pertanyaan dalam proses pembelajaran semakin meningkat, ini ditandai dengan adanya kemampuan siswa untuk menemukan sendiri jawaban soal-soal yang diberikan oleh guru, Serta semakin aktifnya siswa dalam proses pembelajaran. Hal ini ditandai dengan semakin banyaknya siswa yang bertanya dan menjawab soal-soal latihan dan adanya siswa yang lain yang bisa membimbing teman yang lain. Hal ini juga didukung dengan hasil penelitian Khalik Munardy Abu Kasim, K.M.A， dkk (2017;275) bahwa Mempelajari lebih detail mengenai skenario pembelajaran yang ada di Rencana Pelaksanaan Pembelajaran dan berusaha mengoptimalkan kegiatan pembelajaran yang berdasar kehidupan atau menggunakan contoh nyata.

\section{KESIMPULAN DAN SARAN}

Berdasarkan hasil pembahasan bahwa respon belajar siswa mengalami peningkatan. Dilihat dari respon belajar siswa yaitu mengalami peningkatan dari siklus I rata-rata sebesar 69,78 kategori cukup menjadi 78,94 pada siklus II dengan kategori Baik. Begitu juga dengan persentase ketuntasan klasikal hasil belajar siswa, dimana pada siklus I ketuntasan klasikal hanya mencapai $78,79 \%$ meningkat menjadi $87,89 \%$ pada siklus II artinya dari hasil menerapkan model pembelajaran Cooperative tipe index card match dapat meningkatkan hasil belajar siswa pada 
materi pokok fungsi komposisi dan fungsi invers.

Hasil penelitian ini secara langsung mendukung penelitian sebelumnya yang menyatakan bahwa metode koopertif yang menempatkan siswa sebagai obyek didik yang pusat pembelajaran, sehingga dengan demikian dapat memacu mengkonstruksi diri menemukan berbagai kekurangan dan menemukan sendiri solusi atas persoalnnya. Sehingga dalam hasil penelitian ini perlu dikembangkan dalam materi pokok yang lain pada mata pelajaran matematika untuk siswa SMA/SMK.

\section{DAFTAR PUSTAKA}

Arikunto, S. dkk. 2010. Penelitian Tindakan Kelas. Jakarta:Bumi Aksara.

Huda, M. 2011. Cooperatif Learning Metode, Teknik, Struktur dan Model Penerapan. Yogyakarta: Pustaka Pelajar

Khalik, M.A.K., dkk. 2017. Penerapan Model Pembelajaran Realistic Mathematics Education Untuk Meningkatkan Hasil Belajar Siswa Pada Materi Segitiga Kelas VII SMPN 2 Pujut. Prosiding. Seminar Nasional Pendidik dan Pengembang Pendidikan Indonesia. ISSN 2598-1978. Hal. 271-277.

Suprijono, A. 2011. Cooperative Learning Teori \& Aplikasi Paikem. Yokyakarta: Pustaka Pelajar.

Syahrir. 2010. Metodologi Pembelajaran Matematika. Naufan Pustaka:Yogyakarta

Syahrir, dan Elma. H. 2017. Analisis Mind Map Siswa Kelas VII.C SMPN
6 Kopang. JIME. Volume 3 Nomor

1. ISSN 2442-9511. Hal. 421-434. 